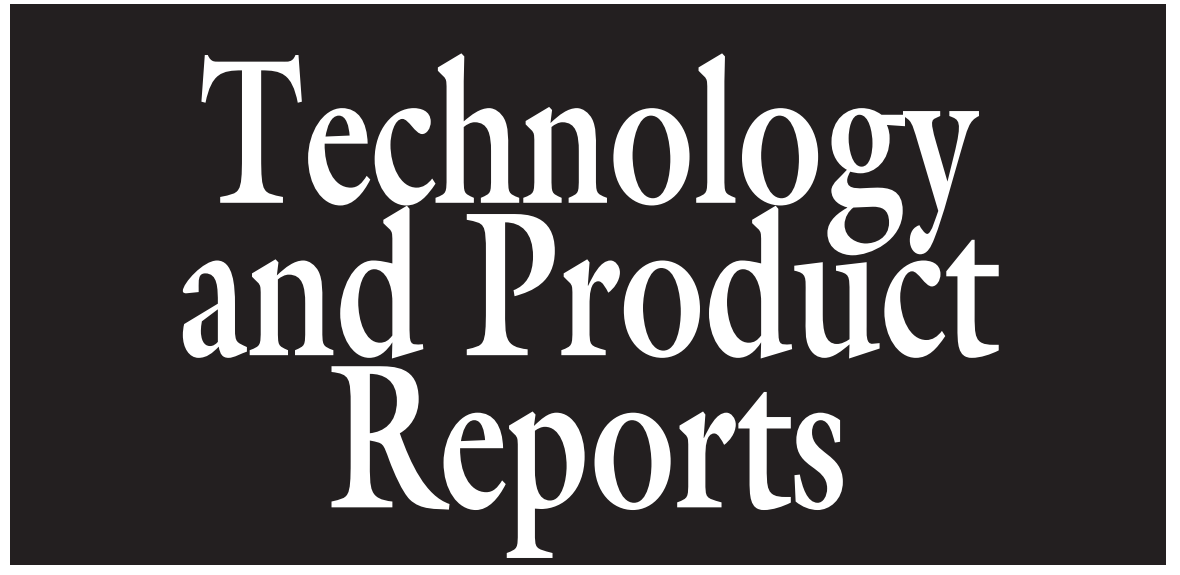

\section{Effect of Seed Treatment, In-furrow, and Foliar Application of Insecticides on the Carrot Weevil in Processing Carrot}

\author{
Melissa Bonham ${ }^{1}$, Gerald M. Ghidiu' ${ }^{2,5}$, Erin Hitchner ${ }^{3}$, \\ and Elwood L. Rossell ${ }^{4}$
}

ADDITIONAL INDEX wORDs. Listronotus oregonensis, Daucus carota, fipronil, diazinon, thiamethoxam, spinosad, pest management

SuMMARY. Field studies were conducted in 2004 and 2005 to determine the effectiveness of a seed treatment, an in-furrow treatment, and foliar applications of insecticides for control of the carrot weevil [Listronotus oregonensis (Coleoptera: Curculionidae)] in processing carrot (Daucus carota). Carrot seed treated with fipronil resulted in significantly less root damage at harvest then did the in-furrow application of thiamethoxam or multiple foliar applications of diazinon or spinosad in both years, and resulted in significantly higher yields compared with all other treatments in 2004. Seed treatments with fipronil should be considered for future registration on carrot. Such registration would allow early to midseason protection of carrot from weevil damage and compliment the current management program of foliar sprays to control adult weevils.

$\mathrm{T}$ he carrot weevil is the most economically important insect pest of carrot in the northeastern United States (Simonet and Davenport, 1981). In New Jersey, adults overwinter in and near hedgerows and fields where carrots were

We thank the farm supervisor, Mr. W. Pompper, for his generous assistance and time helping to establish and maintain this project, and J. Ingersol-Mahar for his harvesting assistance.

New Jersey Agricultural Experiment Station publication No. D-08-08185-02-09. Supported by state funds and by the United States Hatch Act.

${ }^{1} 726$ Barrett's Run Road, Shiloh, NJ 08353

${ }^{2}$ Extension Specialist, Rutgers University, 121 Northville Road, Bridgeton, NJ 08302

${ }^{3}$ Syngenta Crop Protection, 380 Jefferson Road, Elmer, NJ 08318

${ }^{4}$ Marlboro Farms, Bridgeton-Shiloh Pike, Shiloh, NJ 08353

${ }^{5}$ Corresponding author. E-mail: ghidiu@aesop.rutgers. edu. late April to early May (Ryser, 1975). Adults feed directly on leaves and crowns of carrots, and females oviposit from early May through June in carrot roots (Ryser, 1975). Larvae tunnel extensively throughout the upper more of the carrots in untreated fields (Zimmerman et al., 2004). Pepper grown the previous year, emerging in third of the roots, damaging $80 \%$ or
(1942) reported two full broods with a partial third brood in northern New Jersey, and three full broods with a partial fourth in southern New Jersey.

Growers currently use multiple foliar sprays of diazinon, esfenvalerate, or cyfluthrin for control of carrot weevil; no other insecticides are labeled for use on carrot in New Jersey. Control of the carrot weevil is difficult because the female deposits her eggs directly in the roots, thus eliminating the potential for larval control. Consequently, pesticide applications are directed at adults to prevent or reduce oviposition. Carrot weevil damage has been increasing on New Jersey carrot farms during the past several years, and yield losses exceeded $75 \%$ on farms in Salem County in 2002 and 2003. These losses may partly be due to the cancellation of persistent broad-spectrum insecticides once labeled for carrot weevil control, such as parathion, azinphos-methyl, and phosmet, until the early 1990s. Additionally, the increase in carrot weevil damage may also be attributed to limited acreage for crop rotation, an important pest management tactic for carrot weevil (Grafius, 1984).

Seed treatment technologies have advanced rapidly during the past few years, and various seed treatments have effectively controlled a wide range of pests in many crops. There is evidence that fipronil, a relatively new phenylpyrazole insecticide that interferes with the gamma-aminobutyric acid (GABA) receptors of insect neurons, may be useful as a seed treatment for control of carrot weevils. Fipronil is highly toxic to Coleopterans, including weevils, and is systemic in plants (U.S. Environmental Protection Agency, 1996). In field trials, it has been successfully used as a seed treatment for control of the rice water weevil [Lissorhoptrus oryzophilus (Coleoptera: Cucurlionidae)] (Walsh and Johnson,

\begin{tabular}{llll}
\hline $\begin{array}{l}\text { Units } \\
\begin{array}{l}\text { To convert U.S. to SI, } \\
\text { multiply by }\end{array}\end{array}$ & U.S. unit & SI unit & $\begin{array}{l}\text { To convert SI to U.S., } \\
\text { multiply by }\end{array}$ \\
\hline $112.085 \mathrm{l}$ & $\mathrm{cwt} / \mathrm{acre}$ & $\mathrm{kg} \cdot \mathrm{ha}^{-1}$ & 0.0089 \\
0.3048 & $\mathrm{ft}$ & $\mathrm{m}$ & 3.2808 \\
9.3540 & $\mathrm{gal} / \mathrm{acre}$ & $\mathrm{L} \cdot \mathrm{ha}^{-1}$ & 0.1069 \\
2.54 & inch $(\mathrm{es})$ & $\mathrm{cm}$ & 0.3937 \\
0.4536 & $\mathrm{lb}$ & $\mathrm{kg}$ & 2.2046 \\
1.1209 & $\mathrm{lb} / \mathrm{acre}$ & $\mathrm{kg} \cdot \mathrm{ha}^{-1}$ & 0.8922 \\
1.6093 & $\mathrm{mph}$ & $\mathrm{km} \cdot \mathrm{h}^{-1}$ & 0.6214 \\
62.5000 & $\mathrm{oz} / \mathrm{lb}$ & $\mathrm{g} \cdot \mathrm{kg}^{-1}$ & 0.0160 \\
6.8948 & $\mathrm{psi}$ & $\mathrm{kPa}$ & 0.1450
\end{tabular}

Hortlechnology · July-September 2009 19(3) 
2002), cucumber beetle [Acalymma vittatum [Coleoptera: Chrysomelidae]) (Whalen and Spellman, 2005), onion maggot [Delia antiqua (Diptera: Anthomyiidae]) (Nault et al., 2005), and chironomid larva [Chironomus tepperi (Diptera: Chironomidae)] (Stevens et al., 1998).

The present trials were conducted to compare the effectiveness of a seed treatment of fipronil, an infurrow application of thiamethoxam, and multiple foliar applications of spinosad or diazinon directed at the base of the plant for control of the carrot weevil in processing carrot.

\section{Materials and methods}

'Campbell's SDC 1374' carrot (Campbell Seeds, Woodland, CA) were seeded into a Sassafrass sandy loam ( $\mathrm{pH} 5.9$ ) field each year at the Rutgers Agricultural Research and Extension Center, Bridgeton, NJ, with a John Deere Agricola Vacuum Seeder (Deere \& Co., Moline, IL). Each plot consisted of three rows of carrots, 15 inches apart, on a 5 -ft-wide bed that was $25 \mathrm{ft}$ long, replicated four times in a randomized complete block design. All rows were treated, but only the center row was used for data collection. All plots received an application of $60 \mathrm{lb} /$ acre of calcium nitrate $(15 \mathrm{~N}-0 \mathrm{P}-0 \mathrm{~K}$, YaraLiva Tropicote 15-0-0; Yara North America, Tampa, FL), applied I week preplant broadcast and incorporated into the soil, then a second application of 120 $\mathrm{lb} /$ acre of calcium nitrate (YaraLiva Tropicote 15-0-0) was applied and incorporated 4 weeks after planting each year. Herbicide and fungicide maintenance sprays were applied as recommended for carrot production in New Jersey (Garrison, 2004). The seed treatments were prepared and seeds were coated by G. Oliver (BASF Ag Research, Research Triangle Park, NC). The in-furrow treatments were applied with a carbon dioxide-pressurized backpack wand sprayer (R\&D Sprayers, Opelousas, LA) with a single nozzle (8002EVS; Spraying Systems, Wheaton, IL) per row, directed into the row in a 4 -inch band in front of the press wheel at planting using $30 \mathrm{gal} /$ acre at 48 psi. All foliar treatments were applied with a carbon dioxide-pressurized backpack sprayer (R\&D Sprayers) with a single hollow cone nozzle (TXVS18;
Spraying Systems) per row, directed at the base of the plant, using $35 \mathrm{gal} /$ acre at $2 \mathrm{mph}$. Treatments each year were a seed treatment of fipronil $[0.03 \mathrm{lb}$ a.i. per pound of seed (Regent SC; BASF Ag Products, Research Triangle Park, NC)], an infurrow treatment of thiamethoxam [0.125 lb/acre a.i. (Platinum 2SC; Syngenta Crop Protection, Greensboro, NC)], foliar sprays of diazinon $[1.0 \mathrm{lb} /$ acre a.i. (Diazinon 4E; Gowan, Yuma, AZ)], spinosad [0.09 lb/acre a.i. (SpinTor 2F; Dow AgroSciences, Indianapolis, IN)], or an untreated control. Plots were irrigated as needed with an overhead sprinkler.

Each year, 25 carrots from the center row of each plot were harvested, carrots were washed and trimmed, and the number of carrots with weevil damage were counted and recorded; all marketable carrots were weighed. The percentage of damaged carrots was analyzed using the square root transformation, and all data were subjected to a two-way analyses of variance using SAS (version 6.06; SAS Institute, Cary, NC). Separation of the treatment means was de- termined by application of Tukey's honestly significant difference Studentized range tests (version 6.06; SAS) at a probability level of 0.05 .

2004. Carrots were seeded on 22 Apr. Foliar treatments were applied on $4,16,25$ June, and 6, 16, and 26 July. On 28 May, 25 carrot seedlings in the center of each plot were counted and marked with a 12 -inch-long wooden stake at the beginning and the end of those seedlings. The number of plants between the stakes was recounted on 18 June to determine seedling loss. Twenty-five carrots from the center row of each plot were harvested on 6 Aug., washed, trimmed, and the numbers of carrot-weevil damaged roots were recorded to determine the percentage of damaged carrots. Total weights of carrots from each treatment were then recorded.

2005. Carrots were seeded on 4 Apr. Foliar treatments were applied on $7,15,22,30$ June and 8 July. On 20 May, 25 carrot seedlings in the center of each plot were counted and marked as in 2004. The numbers of plants between the stakes were recounted on l July. Twenty-five

Table 1. Insecticide treatment effects on damage to carrot seedlings and carrots by carrot weevil and resulting yields in 2004 .

\begin{tabular}{lccc}
\hline $\begin{array}{l}\text { Insecticide } \\
\text { treatments }^{\mathrm{z}}\end{array}$ & $\begin{array}{c}\text { Seedlings on 18 June } \\
\text { (no./25 seeded) }\end{array}$ & $\begin{array}{c}\text { Damaged carrots on } \\
\text { 2 Sept. (\%) }\end{array}$ & $\begin{array}{c}\text { Total yield on } \\
\text { 2 Sept. (cwt/acre) }\end{array}$ \\
\hline Fipronil & $25.0 \mathrm{a}^{\mathrm{x}}$ & $9.0 \mathrm{a}$ & $703.9 \mathrm{a}$ \\
Thiamethoxam & $25.0 \mathrm{a}$ & $65.3 \mathrm{~b}$ & $175.4 \mathrm{~b}$ \\
Diazinon & $23.3 \mathrm{a}$ & $76.8 \mathrm{bc}$ & $259.4 \mathrm{~b}$ \\
Spinosad & $25.0 \mathrm{a}$ & $81.2 \mathrm{bc}$ & $177.9 \mathrm{~b}$ \\
Untreated & $23.8 \mathrm{a}$ & $89.0 \mathrm{c}$ & $69.2 \mathrm{~b}$ \\
SE & 0.600 & 4.581 & 74.148 \\
\hline
\end{tabular}

${ }^{2}$ Insecticide treatments of fipronil were applied as a seed treatment $(0.03 \mathrm{oz}$ a.i. per pound of seed $)$; thiamethoxam was applied to the soil $(0.125 \mathrm{lb} /$ acre a.i. $)$; diazinon and spinosad were applied as a foliar spray $(0.5 \mathrm{and} 0.1 \mathrm{lb} / \mathrm{acre}$ a.i., respectively, on 4, 16, 25, June and 6, 16, $26 \mathrm{July}) ; 1 \mathrm{oz} / \mathrm{lb}=62.5000 \mathrm{~g} \cdot \mathrm{kg}^{-1}, \mathrm{l} \mathrm{lb} / \mathrm{acre}=1.1209 \mathrm{~kg} \cdot \mathrm{ha} \mathrm{a}^{-1}$. ${ }^{\mathrm{y}} \mathrm{l} \mathrm{cwt} / \mathrm{acre}=112.085 \mathrm{l} \mathrm{kg} \cdot \mathrm{ha}^{-1}$.

xAny two means within a column not followed by the same letter are significantly different via Tukey's honestly significant difference Studentized range tests at $P \leq 0.05$

Table 2. Insecticide treatment effects on damage to carrot seedlings and carrots by carrot weevil and resulting yields in 2005 .

\begin{tabular}{lccc}
\hline Treatment $^{\mathrm{z}}$ & $\begin{array}{c}\text { Seedlings on 1 July } \\
\text { (no./25 seeded) }\end{array}$ & $\begin{array}{c}\text { Damaged carrots } \\
\text { on 29 Aug. (\%) }\end{array}$ & $\begin{array}{c}\text { Total yield on } \\
\text { 29 Aug. (cwt/acre) }\end{array}$ \\
\hline Fipronil ST & $24.8 \mathrm{a}^{\mathrm{x}}$ & $27.7 \mathrm{a}$ & $832.1 \mathrm{a}$ \\
Thiamethoxam 2SC & $24.8 \mathrm{a}$ & $73.3 \mathrm{~b}$ & $695.8 \mathrm{a}$ \\
Diazinon 4EC & $24.0 \mathrm{a}$ & $77.6 \mathrm{~b}$ & $717.3 \mathrm{a}$ \\
Spinosad 2F & $22.7 \mathrm{a}$ & $85.4 \mathrm{~b}$ & $760.3 \mathrm{a}$ \\
Untreated & $24.5 \mathrm{a}$ & $79.7 \mathrm{~b}$ & $698.5 \mathrm{a}$ \\
SE & 0.784 & 2.619 & 70.298 \\
\hline
\end{tabular}

${ }^{\mathrm{z}}$ Insecticide treatments of fipronil were applied as a seed treatment $(0.03 \mathrm{oz}$ a.i. per pound of seed $)$; thiamethoxam was applied to the soil $(0.125 \mathrm{lb} /$ acre a.i. $)$; diazinon and spinosad were applied as a foliar spray $(0.5$ and $0.1 \mathrm{lb} / \mathrm{acre}$ a.i., respectively, on $7,15,22,30 \mathrm{June}$ and $8 \mathrm{July}) ; \mathrm{l} \mathrm{oz} / \mathrm{lb}=62.5000 \mathrm{~g} \cdot \mathrm{kg}^{-1}, 1 \mathrm{lb} / \mathrm{acre}=1.1209 \mathrm{~kg} \cdot \mathrm{ha}^{-1}$. ${ }^{\mathrm{y}} \mathrm{l} \mathrm{cwt} / \mathrm{acre}=112.0851 \mathrm{~kg} \cdot \mathrm{ha}^{-1}$

${ }^{x}$ Any two means within a column not followed by the same letter are significantly different via Tukey's honestly significant difference Studentized range tests at $P \leq 0.05$ 
carrots from the center row or each plot were harvested on 29 Aug., washed, trimmed, and the numbers of carrot-weevil damaged roots were recorded. Total weights of carrots for each treatment were then recorded.

\section{Results}

In 2004 and 2005, the numbers of seedlings damaged or destroyed early in the season (April-May) by the carrot weevil were not significantly different $(\mathrm{F}=1.339 ; \mathrm{df}=4,12 ; P=$ 0.05 and $\mathrm{F}=1.149 ; \mathrm{df}=4,12 ; P=$ 0.05 , respectively) among treatments (Tables 1 and 2 ).

In 2004, the percentage of carrots with weevil damage at harvest was significantly $(\mathrm{F}=23.962 ; \mathrm{df}=4$, $12 ; P=0.05)$ lower in plots that received the fipronil seed treatment compared with all other treatments (Table 1), while the in-furrow treatment of thiamethoxam only had significantly less damage than did the untreated; there were no significant differences for damaged carrots among thiamethoxam or the foliar sprays of diazinon or spinosad (Table 1). Plots that received the fipronil seed treatment also had significantly $(\mathrm{F}=11.219 ; \mathrm{df}=4,12 ; P=0.05)$ higher total yields in 2004 compared with all other treatments.

In 2005, carrot weevil pressure was extremely high, as shown by the percentage of damage to the carrots in all plots ( $>73 \%$ damage) except the seed-treated plots $(28 \%$ damage $)$. Although this damage was commercially unacceptable in all plots, including the seed treated plots, the fipronil seed treatment again resulted in significantly $(\mathrm{F}=15.628 ; \mathrm{df}=4,12$; $P=0.05$ ) less weevil damage than all other treatments. At harvest, there were no significant yield differences (total carrot weights) among treatments $(\mathrm{F}=0.663 ; \mathrm{df}=4,12 ; P=$ 0.05 ) (Table 2).

\section{Discussion}

In these trials, there were no significant differences among treatments in the numbers of seedlings damaged or destroyed early in the season by the carrot weevil either year. Although carrot weevils are attracted to carrot before the plants reach the six-leaf stage, early damage is usually confined to minor feeding to the leaves and petioles (Cress and Wells, 1977), and such damage would likely have little effect on yields, as carrot roots are only starting to develop.

Plots that received the fipronil seed treatment had significantly less carrot weevil damage at harvest than did all other treatments in 2004 and 2005. Ryser (1975) reported that the highest numbers of adult weevils caught in carrot weevil traps in New Jersey occurred before early summer, and the population then decreased in June and July until early fall. If a seed treatment or other systemic insecticide protected the carrots until the carrot weevil population declined in mid-June, it would have an advantage over foliar applications of insecticides that would be susceptible to environmental degradation, wind, and rainfall at time of application, and other factors. Thus, protection of carrots through midsummer is critical to preventing or reducing weevil damage to carrots at harvest.

Plots that received the fipronil seed treatment had significantly higher yields compared with all other treatments only in 2004. Carrots damaged by carrot weevils can have extensive tunneling throughout the root, but the plants may still produce large carrots. Boivin (1988) reported that adult feeding, oviposition punctures, and subsequent larval feeding of the carrot weevil in carrot did not decrease carrot stand significantly, although quality decreased.

In conclusion, our studies demonstrate that a fipronil seed treatment for carrot is significantly more effective for carrot weevil control than an infurrow application of thiamethoxam or multiple spray applications of diazinon or spinosad. Seed treatment methods generally require much less a.i. per unit area to provide a comparable level of control relative to other application methods, including in-furrow applications. Taylor et al. (2001) reported that cyromazine seed treatment used less than $85 \%$ a.i. per hectare compared with an in-furrow drench application of chlorpyrifos. The potential registration of this new chemistry insecticide as a seed treatment would provide carrot growers an effective management option for control of carrot weevil in carrot.

\section{Literature cited}

Boivin, G. 1988. Effects of carrot developmental stages on feeding and oviposition of carrot weevil, Listronotus oregonensis (LeConte) (Coleoptera: Curculionidae). Environ. Entomol. 17:330-336.

Cress, D. and A. Wells. 1977. Celery and carrot insect pests. Michigan State Univ. Ext. Bul. E-970.

Garrison, S.A. (ed.). 2004. Commercial vegetable production recommendations for New Jersey. Rutgers Univ. Coop. Ext. Bul. E001T.

Grafius, E.J. 1984. Step-by-step management of the carrot weevil in carrots and celery in Michigan. Pest Profiles, Michigan State Univ. Ext. Fact Sheet PP-9.

Nault, B., R.W. Straub, and A.G. Taylor. 2005. Performance of novel insecticide seed treatments for managing onion maggot (Diptera: Anthomyliidae) in onion fields. Crop Prot. 25:58-65.

Pepper, B.B. 1942. The carrot weevil, Listronotus latiusculus (Bohe.) in New Jersey and its control. New Jersey Agr. Expt. Sta. Bul. 693.

Ryser, B.W. 1975. Investigations regarding the biology and control of the carrot weevil, Listronotus oregonensis (LeConte) in New Jersey. Rutgers Univ., New Brunswick, NJ, MS thesis.

Simonet, D.E. and B.L. Davenport. 1981. Temperature requirements for development and oviposition of the carrot weevil. Ann. Entomol. Soc. Amer. 74:312-315.

Stevens, M.M., S. Helliwell, and G.N. Warren. 1998. Fipronil seed treatments for the control of chironomid larvae in aerially-sown rice. Field Crops Res. 57:195-207.

United States Environmental Protection Agency. 1996. New pesticide fact sheet: Fipronil; EPA-737-F-96-005. U.S. Environ. Protection Agency, Office of Prevention, Pesticides, and Toxic Substances. U.S. Government Printing Office, Washington, DC.

Taylor, A.G., C.J. Eckenrode, and R.W. Straub. 2001. Seed coating technologies and treatments for onion: Challenges and progress. HortScience 36:199-205.

Walsh, K.D. and D.R. Johnson. 2002. Rice water weevil control in water-seeded rice. Arkansas Expt. Sta. Res. Ser. 504

Whalen, J. and M. Spellman. 2005. Insect management in cucumbers with seed treatments, p. 4-7. In: University of Delaware integrated pest management results, 2005. Univ. Delaware, Newark.

Zimmerman, M., E. Hitchner, G.M. Ghidiu, and E. Rossell. 2004. Control of carrot weevil in processing carrots, $\mathrm{p}$. 2-3. In: Vegetable entomology research results. New Jersey Agr. Expt. Sta. Bul. 104M. 